\title{
Cutaneous Miliary Tuberculosis in a Chronic Kidney Disease Patient
}

\author{
Pudit Suraprasit Narumol Silpa-archa Daranporn Triwongwaranat \\ Department of Dermatology, Siriraj Hospital, Mahidol University, Bangkok, Thailand
}

\section{Key Words}

Tuberculosis · Cutaneous · Cutaneous military tuberculosis · Chronic kidney disease

\begin{abstract}
A 79-year-old Thai woman with advanced renal failure, dyslipidemia and anemia of chronic disease was admitted to hospital with prolonged fever, productive cough and multiple discrete small pustules on her face, trunk and extremities. A chest X-ray revealed diffuse miliary infiltration. Mycobacterium tuberculosis complex DNA was detected by polymerase chain reaction in sputum and scrapings of pustules from her skin. Blood culture identified M. tuberculosis complex. Pulmonary and cutaneous miliary tuberculosis was diagnosed. The patient's symptoms improved after 3 weeks of treatment with isoniazid, rifampicin, ethambutol and pyrazinamide. This report details a case of cutaneous miliary tuberculosis in a non-dialysis chronic kidney disease patient.

(c) 2014 S. Karger AG, Basel
\end{abstract}

\section{Introduction}

Tuberculosis is a common cause of mortality worldwide. Globally, the incidence of all forms of tuberculosis infection was approximately 1.2 million cases per year between 1990 and 2013 [1]. Extrapulmonary tuberculosis infection accounts for $5.8-44.4 \%$ of all tuberculosis cases [2]. This form of tuberculosis affects the lymph nodes, pleura, urinary tract, bones, joints, eyes and skin [3] and is observed more commonly in HIV and immunocompromised patients and patients with chronic diseases such as chronic kidney disease (CKD) than in otherwise healthy people [3,4]. Disseminated tuberculosis presenting with cutaneous lesions is rare [5].

Cutaneous miliary tuberculosis presents a small proportion of all cutaneous tuberculosis cases [6]. This variant is usually reported in children, HIV and immunocompromised patients [5-7]. Generally, cutaneous miliary tuberculosis shows a hematogenous spread of

Daranporn Triwongwaranat, MD

Department of Dermatology, Siriraj Hospital, Mahidol University

9th Floor Chalermprakiat Building

Bangkok 10700 (Thailand)

E-Mail d.triwongwaranat@gmail.com 
infection and is commonly seen in advanced pulmonary or disseminated tuberculosis [5]. Here, we report a case of pulmonary tuberculosis with cutaneous miliary tuberculosis in a CKD patient.

\section{Case Report}

A 79-year-old Thai woman with a history of CKD stage 5 (serum creatinine level 4.5$5.0 \mathrm{mg} / \mathrm{dl}$ ), dyslipidemia and anemia of chronic disease presented with fatigue, low-grade fever and a productive cough for the last 2 months. She denied any history of tuberculosis infection. Her current medication was manidipine hydrochloride $(10 \mathrm{mg} /$ day $)$ and furosemide (20 mg/day). Physical examination revealed fever, fine crepitation in both lungs and multiple discrete small pustules on her face, trunk and extremities (fig. 1). Laboratory findings showed a hemoglobin level of $9.2 \mathrm{~g} / \mathrm{dl}$, a white cell count of $21,060 / \mathrm{mm}^{3}$ with $91.2 \%$ neutrophils, and a platelet count of $210,000 / \mathrm{mm}^{3}$. An anti-HIV test was negative. Radiography of the chest revealed diffuse reticulonodular infiltration of both lungs. Sputum examination was positive for acid-fast bacilli and Mycobacterium tuberculosis complex DNA was detected by polymerase chain reaction. Skin scrapings from pustules of the right thigh were positive for acid-fast bacilli and $M$. tuberculosis complex DNA was detected by polymerase chain reaction. She was diagnosed with pulmonary and cutaneous miliary tuberculosis. Blood cultures identified M. tuberculosis complex 50 days later. She was started on an initial therapy of isoniazid ( $300 \mathrm{mg}$ /day), rifampicin $(450 \mathrm{mg} /$ day), ethambutol $(800 \mathrm{mg} /$ day) and pyrazinamide $(1,500 \mathrm{mg} /$ day). The pustules subsided after 3 weeks of treatment and pulmonary symptoms improved after 5 weeks of treatment.

\section{Discussion}

The incidence of cutaneous tuberculosis has increased with the resurgence of pulmonary tuberculosis. Cutaneous tuberculosis accounts for $1.5 \%$ of all extrapulmonary tuberculosis cases [4]. The mechanism of cutaneous tuberculosis consists of direct inoculation, contiguous infection of the organs (e.g. lymph nodes, bones, joints), hematogenous dissemination or a hypersensitivity reaction against $M$. tuberculosis $[3,5]$. Conditions predisposing people to disseminated tuberculosis include HIV infection, immunosuppressive therapy, alcoholism, diabetes mellitus, hematologic disorders, being elderly and chronic diseases $[3,8]$. The patient in this report was elderly with CKD. CKD can cause cellular immune impairments, making a person susceptible to tuberculosis.

The manifestation of cutaneous miliary tuberculosis is nonspecific. The lesions can be generalized discrete erythematous papules, pustules or vesicles [5]. Our patient presented with prolonged fever with multiple discrete small pustules on her face, trunk and extremities. Other causes of disseminated infection (bacteria, fungus, herpesvirus, non-tuberculous mycobacteria) and acute febrile neutrophilic dermatosis should be excluded. We suspected cutaneous miliary tuberculosis based on the clinical presentation of pustules and confirmed the diagnosis by identification of the organism in skin lesions. Following treatment with antituberculosis agents, the patient's fever and pustules resolved within 3 weeks. The cutaneous remission is responsive similar to previous case reports [7, 9].

The gold standard for the diagnosis of cutaneous tuberculosis is the identification of M. tuberculosis from a skin biopsy. Significant response to a therapeutic trial of anti-tuberculosis agents for 6 weeks can suggest cutaneous tuberculosis [10]. Subsequent isolation of 
M. tuberculosis in blood cultures supports the mechanism of hematogenous spread in cutaneous miliary tuberculosis [5].

Before the era of HIV infection, cutaneous miliary tuberculosis occurred predominantly in infants. In a review published in 1991, Rietbroek et al. [11] described 24 cases in adult patients with virtually no underlying illnesses. Recently, such a condition tends to occur in HIV and immunocompromised adult patients [3, 6-8, 12]. Only a few cases of disseminated M. tuberculosis of the skin in renal transplant recipients or CKD patients have been reported with the various clinical manifestations (table 1). A common feature of these cases is chronic immunosuppressive therapy.

\section{Conclusion}

This case highlights that a rare cutaneous manifestation with a hematogenous dissemination of M. tuberculosis can develop in immunocompromised patients, such as those with HIV, on immunosuppressive therapy and even with CKD.

\section{References}

$\longrightarrow 1$ Murray CJ, Ortblad KF, Guinovart C, Lim SS, Wolock TM, Roberts DA, et al: Global, regional, and national incidence and mortality for HIV, tuberculosis, and malaria during 1990-2013: a systematic analysis for the Global Burden of Disease Study 2013. Lancet 2014;384:1005-1070.

2 Sandgren A, Hollo V, van der Werf MJ: Extrapulmonary tuberculosis in the European Union and European Economic Area, 2002 to 2011. Euro Surveill 2013;18.

3 Daido-Horiuchi Y, Kikuchi Y, Kobayashi S, Fujii T, Oshima S, Kondo T: Tuberculous cellulitis in a patient with chronic kidney disease and polymyalgia rheumatica. Intern Med 2012;51:3203-3206.

4 Mehta PK, Raj A, Singh N, Khuller GK: Diagnosis of extrapulmonary tuberculosis by PCR. FEMS Immunol Med Microbiol 2012;66:20-36.

-5 Bravo FG, Gotuzzo E: Cutaneous tuberculosis. Clin Dermatol 2007;25:173-180.

-6 Marcoval J, Alcaide F: Evolution of cutaneous tuberculosis over the past 30 years in a tertiary hospital on the European Mediterranean coast. Clin Exp Dermatol 2012;38:131-136.

-7 Yodmalai S, Chiewchanvit S, Mahanupab P: Cutaneous miliary tuberculosis in a renal transplant patient: a case report and literature review. Southeast Asian J Trop Med Public Health 2011;42:674-678.

$\rightarrow 8$ Crump JA, Reller LB: Two decades of disseminated tuberculosis at a university medical center: the expanding role of mycobacterial blood culture. Clin Infect Dis 2003;37:1037-1043.

-9 Park KW, Kim US, Shin JW, Yoo CG, Oh MD, Choe K: Disseminated erythematous papules in a renal transplant recipient: a case of disseminated tuberculosis. Scand J Infect Dis 2002;34:775-777.

10 Ramam M, Mittal R, Ramesh V: How soon does cutaneous tuberculosis respond to treatment? Implications for a therapeutic test of diagnosis. Int J Dermatol 2005;44:121-124.

11 Rietbroek RC, Dahlmans RP, Smedts F, Frantzen PJ, Koopman RJ, van der Meer JW: Tuberculosis cutis miliaris disseminata as a manifestation of miliary tuberculosis: literature review and report of a case of recurrent skin lesions. Rev Infect Dis 1991;13:265-269.

12 Daikos GL, Uttamchandani RB, Tuda C, Fischl MA, Miller N, Cleary T, Saldana MJ: Disseminated miliary tuberculosis of the skin in patients with AIDS: report of four cases. Clin Infect Dis 1998;27:205-208.

13 Ram R, Uppin S, Swarnalatha G, Desai M, Harke M, Prasad N, Dakshinamurty KV: Isolated skin ulcers due to Mycobacterium tuberculosis in a renal allograft recipient. Nat Clin Pract Nephrol 2007;3:688-693.

14 Seyahi N, Apaydin S, Kahveci A, Mert A, Sariyar M, Erek E: Cellulitis as a manifestation of miliary tuberculosis in a renal transplant recipient. Transpl Infect Dis 2005;7:80-85.

-15 Maejima H, Arai S, Ebata T, Takeda H, Kusunoki M, Katsuoka K: Tuberculous gumma associated with idiopathic thrombocytopenic purpura: report of a Japanese female patient. J Dermatol 2007;34:86-91. 


\section{Case Reports in Dermatology}

\begin{tabular}{l|l}
\hline Case Rep Dermatol 2014;6:253-257 \\
\hline DOI: $10.1159 / 000369156$ & $\begin{array}{l}\text { C 2014 S. Karger AG, Basel } \\
\text { www.karger.com/cde }\end{array}$ \\
\hline
\end{tabular}

Suraprasit et al.: Cutaneous Miliary Tuberculosis in a Chronic Kidney Disease Patient

Table 1. Summary of cases of disseminated cutaneous tuberculosis in CKD patients

\begin{tabular}{|c|c|c|c|c|c|c|c|}
\hline $\begin{array}{l}\text { Number of } \\
\text { patients } \\
\text { [reference] }\end{array}$ & $\begin{array}{l}\text { Gender/ } \\
\text { age } \\
\text { (years) }\end{array}$ & $\begin{array}{l}\text { Underlying } \\
\text { disease }\end{array}$ & $\begin{array}{l}\text { Immunosuppressive } \\
\text { therapy }\end{array}$ & $\begin{array}{l}\text { Duration of } \\
\text { immuno- } \\
\text { suppressive } \\
\text { therapy }\end{array}$ & $\begin{array}{l}\text { Form of cutaneous } \\
\text { tuberculosis }\end{array}$ & $\begin{array}{l}\text { Anti- } \\
\text { tubercu- } \\
\text { losis } \\
\text { therapy }\end{array}$ & $\begin{array}{l}\text { Time for } \\
\text { cutaneous } \\
\text { complete } \\
\text { remission }\end{array}$ \\
\hline $1[4]$ & $\begin{array}{l}\text { male/ } \\
89\end{array}$ & $\begin{array}{l}\text { CKD, } \\
\text { polymyalgia } \\
\text { rheumatica }\end{array}$ & prednisolone $5 \mathrm{mg} /$ day & 13 years & $\begin{array}{l}\text { tuberculous } \\
\text { cellulitis }\end{array}$ & yes & NA \\
\hline $2[7]$ & $\begin{array}{l}\text { male/ } \\
56\end{array}$ & $\begin{array}{l}\text { post renal } \\
\text { transplantation }\end{array}$ & cyclosporin $100 \mathrm{mg} /$ day & NA & $\begin{array}{l}\text { cutaneous miliary } \\
\text { tuberculosis }\end{array}$ & yes & 2 weeks \\
\hline 3 [9] & $\begin{array}{l}\text { female/ } \\
62\end{array}$ & $\begin{array}{l}\text { post renal } \\
\text { transplantation }\end{array}$ & $\begin{array}{l}\text { azathioprine } 100 \mathrm{mg} / \text { day; } \\
\text { prednisolone } 10 \mathrm{mg} / \text { day }\end{array}$ & 16 years & $\begin{array}{l}\text { cutaneous miliary } \\
\text { tuberculosis }\end{array}$ & yes & 3 days \\
\hline 4 [13] & $\begin{array}{l}\text { male/ } \\
27\end{array}$ & $\begin{array}{l}\text { post renal } \\
\text { transplantation }\end{array}$ & cyclosporin $3 \mathrm{mg} / \mathrm{kg} /$ day & 12 years & leg ulcers & yes & 7 weeks \\
\hline $5[14]$ & $\begin{array}{l}\text { male/ } \\
37\end{array}$ & $\begin{array}{l}\text { post renal } \\
\text { transplantation }\end{array}$ & $\begin{array}{l}\text { azathioprine } 100 \mathrm{mg} / \text { day; } \\
\text { methylprednisolone } 8 \mathrm{mg} / \text { day }\end{array}$ & 14 years & $\begin{array}{l}\text { tuberculous } \\
\text { cellulitis }\end{array}$ & yes & 3 weeks \\
\hline $6[15]$ & $\begin{array}{l}\text { female/ } \\
77\end{array}$ & CKD, ITP & prednisolone $15 \mathrm{mg} /$ day & 4 years & $\begin{array}{l}\text { tuberculous } \\
\text { gumma }\end{array}$ & yes & $\begin{array}{l}\text { several } \\
\text { months }\end{array}$ \\
\hline $\begin{array}{l}\text { Current } \\
\text { case }\end{array}$ & $\begin{array}{l}\text { female/ } \\
79\end{array}$ & CKD & no & - & $\begin{array}{l}\text { cutaneous miliary } \\
\text { tuberculosis }\end{array}$ & yes & 3 weeks \\
\hline
\end{tabular}

ITP = Idiopathic thrombocytopenic purpura; NA = data not available. 
Suraprasit et al.: Cutaneous Miliary Tuberculosis in a Chronic Kidney Disease Patient
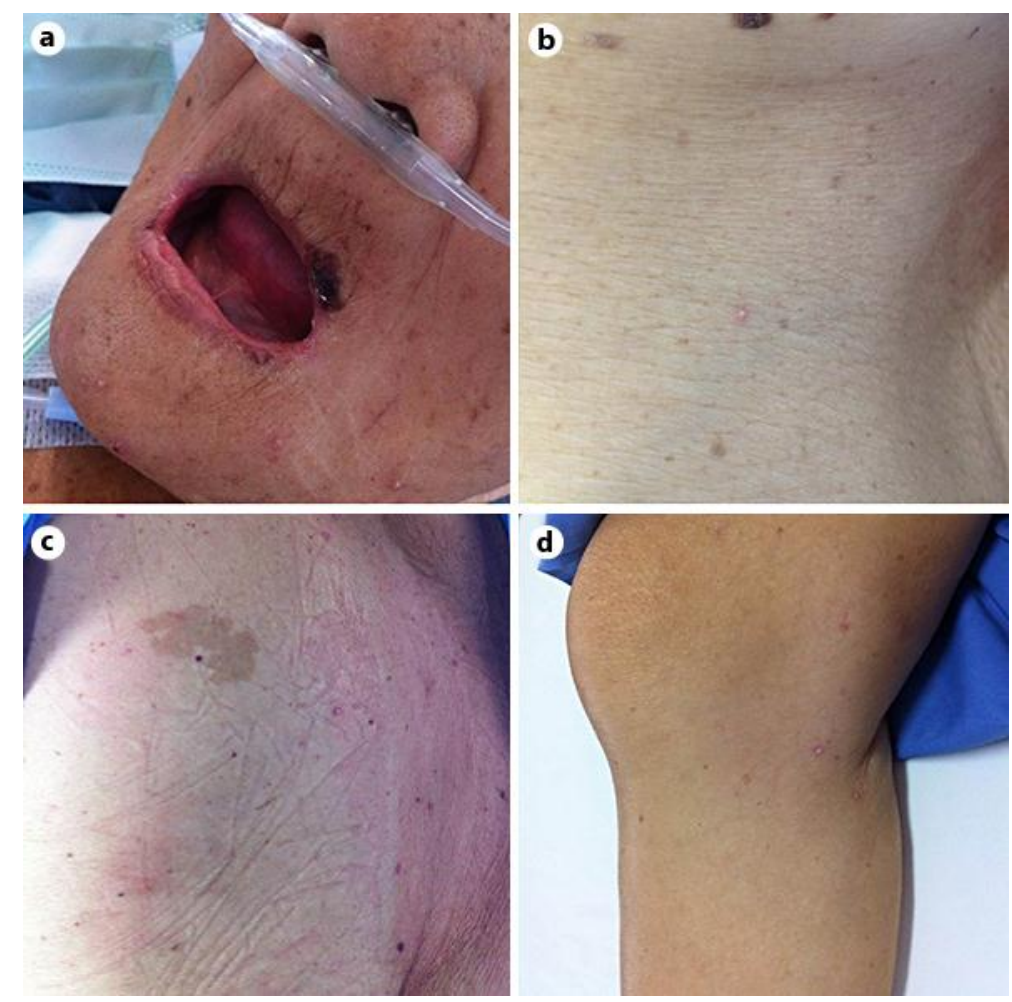

Fig. 1. Multiple discrete small pustules distributed on the face (a), trunk (b) and extremities (c, d). 